\title{
Single-dose infliximab in hepatitis $C$ genotype 1 treatment- naive patients with high serum levels of tumour necrosis factor-alpha does not influence the efficacy of pegylated interferon alpha-2b/ribavirin therapy
}

\author{
Curtis Cooper $M D^{1}$, Stephen Shafran $M D^{2}$, Susan Greenbloom $M^{3}$, Robert Enns $M D^{4}$, John Farley $M^{5}$, \\ Nir Hilzenrat $\mathrm{MD}^{6}$, Kurt Williams $\mathrm{MD}^{7}$, Magdy Elkashab MD ${ }^{8}$, Nabil Abadir MD ${ }^{9}$, Manuela Neuman $\mathrm{PhD}^{10}$
}

\begin{abstract}
C Cooper, S Shafran, S Greenbloom, et al. Single-dose infliximab in hepatitis $\mathrm{C}$ genotype 1 treatment-naive patients with high serum levels of tumour necrosis factor-alpha does not influence the efficacy of pegylated interferon alpha-2b/ribavirin therapy. Can J Gastroenterol Hepatol 2014;28(1):35-40.
\end{abstract}

BACKGROUND: Serum tumour necrosis factor-alpha (TNF- $\alpha$ ) levels correlate negatively with hepatitis $\mathrm{C}$ virus (HCV) antiviral response. OBJECTIVES: To test the hypothesis that a single infliximab induction dose would positively influence on-treatment virological response and sustained virological response (SVR).

METHODS: The present study was a phase IIIB, randomized, prospective, open-label pilot trial conducted at eight Canadian sites. Treatment-naive HCV genotype 1 -infected patients 18 to 65 years of age with high serum TNF- $\alpha$ values $(>300 \mathrm{pg} / \mathrm{mL})$ were randomly assigned to receive a single pretreatment induction infliximab infusion $(5 \mathrm{mg} / \mathrm{kg}$ ) seven days before antiviral therapy (arm A) or no pretreatment (arm B). All patients received pegylated interferon $\alpha 2 \mathrm{~b}(1.5 \mu \mathrm{g} / \mathrm{kg} / \mathrm{week})$ plus weight-based ribavirin ( $800 \mathrm{mg} /$ day to $1400 \mathrm{mg} /$ day) for up to 48 weeks.

RESULTS: Eighty-five patients (arm A [ $\mathrm{n}=41]$, arm B [n=44]; 70\% male) received pegylated interferon $\alpha 2 \mathrm{~b}$. The mean age (48.1 years), race ( $81 \%$ white) and METAVIR fibrosis stage (FO-2 = 79\%, F3-4 = 21\%) were similar between groups. Infliximab was well tolerated without attributable severe adverse events; $56.5 \%$ completed the study ( $\operatorname{arm~A~[n=21],~}$ $\operatorname{arm~B~[n=27]).~Most~discontinuations~were~due~to~virological~failure~at~}$ weeks $12(n=20[23.5 \%])$ and $24(n=7[8.2 \%])$ and did not differ according to group. Numerically lower proportions of infliximab recipients achieved rapid virological response (19.5\% versus $36.4 \%$ ), complete early virological response (43.9\% versus $59.1 \%)$ and SVR (34.1\% versus $52.3 \%)$. However, between-group differences did not reach statistical significance. No differences in adverse event profile or laboratory measures were noted.

CONCLUSION: A single infliximab dose before pegylated-interferon $\alpha 2 \mathrm{~b}$ and ribavirin therapy did not result in greater viral decline during the first 12 weeks of HCV therapy or improved SVR.

Key Words: HCV; Infliximab; Interferon; TNF-alpha; Viral kinetics
Une seule dose d'infliximab chez des patients atteints d'hépatite $C$ de génotype 1 naïfs au traitement présentant des taux sériques élevés de facteur de nécrose tumorale alpha n'influe pas sur l'efficacité d'une thérapie à l'interféron pégylé alpha $2 \mathrm{~b}$ et à la ribavirine

\begin{abstract}
HISTORIQUE : Les taux sériques de facteur de nécrose tumorale alpha (TNF- $\alpha$ ) ont une corrélation négative avec la réponse antivirale au virus de l'hépatite C (VHC).

OBJECTIFS : Vérifier l'hypothèse selon laquelle une seule dose d'induction à l'infliximab aurait une influence positive sur la réponse virologique pendant le traitement et sur la réponse virologique soutenue (RVS).

MÉTHODOLOGIE : Le présent essai pilote ouvert aléatoire et prospectif de phase IIIB a été mené dans huit établissements canadiens. Les chercheurs ont réparti au hasard des patients de 18 à 65 ans infectés par le VHC de génotype 1 naïfs au traitement dont les valeurs de TNF- $\alpha$ étaient élevées (plus de $300 \mathrm{pg} / \mathrm{mL}$ ) entre une seule infusion d'induction d'infliximab (5 mg/kg) sept jours avant l'antivirothérapie (volet $\mathrm{A}$ ) et aucun traitement préalable (volet B). Tous les patients ont reçu de l'interféron pégylé $\alpha 2 \mathrm{~b}(1,5 \mu \mathrm{g} / \mathrm{kg} /$ semaine) associé à de la ribavirine administrée selon le poids $(800 \mathrm{mg} /$ jour à $1400 \mathrm{mg} /$ jour $)$ pendant un maximum de 48 semaines.

RÉSULTATS : Quatre-vingt-cinq patients (volet A [ $\mathrm{n}=41$ ], volet $\mathrm{B}$ [n=44]; $70 \%$ d'hommes) ont reçu de l'interféron pégylé $\alpha 2 \mathrm{~b}$. Lâge moyen ( 48,1 ans), la race ( $81 \%$ de blancs) et le stade de fibrose selon la classification Métavir ( $\mathrm{FO}-2=79 \%, \mathrm{~F} 3-4=21 \%$ ) étaient similaires entre les groupes. L'infliximab était bien toléré et ne s'associait à aucuns événements indésirables graves; $56,5 \%$ ont terminé l'étude (volet $A[n=21]$, volet $B$ $[\mathrm{n}=27])$. La plupart des abandons étaient attribuables à un échec virologique lors des semaines $12(\mathrm{n}=20$ [23,5\%]) et $24(\mathrm{n}=7$ [8,2\%]), ce qui ne différait pas entre les groupes. Moins de patients ayant reçu de l'infliximab ont obtenu une réponse virologique rapide (19,5\% par rapport à $36,4 \%)$, une réponse virologique précoce complète $(43,9 \%$ par rapport à $59,1 \%)$ et une RVS (34,1\% par rapport à 52,3\%). Cependant, les différences entre les groupes n'atteignaient pas de signification statistique. Les chercheurs n'ont remarqué aucunes différences sur le plan du profil d'effets indésirables ou des mesures de laboratoire.

CONCLUSION : Une seule dose d'infliximab administrée avant une thérapie à l'interféron pégylé $\alpha 2 \mathrm{~b}$ et à la ribavirine ne suscite pas de diminution de la charge virale ou d'amélioration de la RVS pendant les 12 premières d'une thérapie contre le VHC.
\end{abstract}

Wiral and host factors involved in determining the natural course of
hepatitis $\mathrm{C}$ virus $(\mathrm{HCV})$ disease are only partially defined. It is
known that an effective host response against HCV infection requires
a coordinated effort involving both nonspecific and HCV antigen-
specific immune responses. Nonspecific immune responses include

${ }^{1}$ University of Ottawa, Ottawa Hospital Research Institute, Ottawa, Ontario; ${ }^{2}$ University of Alberta, Edmonton, Alberta; ${ }^{3}$ Toronto Digestive Disease

Associates, Toronto, Ontario; ${ }^{4} \mathrm{St}$ Paul's Hospital, University of British Columbia; ${ }^{5}$ Private Practice, Vancouver, British Columbia; ${ }^{6} \mathrm{Jewish}$ General

Hospital and McGill University, Montreal, Quebec; ${ }^{7}$ Royal University Hospital, Saskatoon, Saskatchewan; ${ }^{8}$ Private practice, Toronto, Ontario;

${ }^{9}$ Merck Canada Inc, Kirkland, Quebec; ${ }^{10}$ University of Toronto, Toronto, Ontario

Correspondence: Dr Curtis Cooper, University of Ottawa, The Ottawa Hospital Division of infectious Diseases, G12-501 Smyth Road, Ottawa,

Ontario K1H 8L6. Telephone 613-737-8924,e-mail ccooper@toh.on.ca

Received for publication September 10, 2013. Accepted September 15, 2013

\begin{abstract}
those of the interferon system, a family of related proteins that act against many phases of the viral life cycle; complement, which can serve to disrupt the viral envelope and lead to enhanced opsonization of viruses by phagocytic cells; and natural killer cells, which lyse
infected cells. Activation of Kupffer cells, which are the resident
\end{abstract}


macrophages within the liver, produce cytokines (eg, tumour necrosis factor-alpha $[$ TNF- $\alpha])$ that have important effects on viral replication and transcription $(1,2)$.

Cytokines are signalling proteins transiently produced after cellular activation (2). Cytokines play a key role in the cell-to-cell communication necessary for the regulation of immunity and inflammation within the liver (2-4). Interferon alpha (IFN- $\alpha$ ), which is a key component of current standard of care for HCV antiviral treatment, is an endogenous cytokine that stimulates $\mathrm{T}$ lymphocyte antiviral response by signalling the immune system to prevent activated T cell death during infection. Evaluation of the cytokine network may provide important insights into the mechanism of viral persistence in chronic HCV infection. In patients with chronic HCV infection, measurement of serum proinflammatory cytokine levels may also be useful for the selection of patients with higher probability of virological response with HCV antiviral therapy (5-9). Furthermore, modulation of the cytokine network may be beneficial as a therapeutic intervention (10).

Infliximab is a chimeric immunoglobulin G16 monoclonal antibody that neutralizes the biological activity of TNF- $\alpha$ by high-affinity binding of soluble and transmembrane forms of TNF- $\alpha$ and inhibition of TNF- $\alpha$ binding with its receptors (11). Given the potential influence of high TNF- $\alpha$ levels on the pathogenesis of HCV infection (12), we evaluated the safety and efficacy of a single, low-dose infliximab induction therapy injection on virological response and sustained virological response (SVR) in HCV-infected study participants receiving pegylated IFN- $\alpha 2 \mathrm{~b}$ and ribavirin-based antiviral treatment.

\section{METHODS}

The present phase IIIB, randomized, prospective, open-label pilot trial was conducted at eight Canadian sites. Treatment-naive HCV genotype 1 -infected patients 18 to 65 years of age with high serum TNF- $\alpha$ levels ( $>300 \mathrm{pg} / \mathrm{mL}$ ) were included. Clinical evidence of liver decompensation and cirrhosis on biopsy were exclusionary. The degree of fibrosis was assessed using METAVIR score. Other exclusion criteria included HCV infection acquired within the preceding 12 months, pregnancy or breastfeeding, hepatitis B virus or HIV coinfection, alcohol consumption $>350 \mathrm{~g}$ per week, injection drug use within six months of screening, active and severe psychiatric illness, and weight $<40 \mathrm{~kg}$ or $>125 \mathrm{~kg}$. Previous exposure to TNF- $\alpha$ inhibitors, interferon or ribavirin was exclusionary. Chronic systemic steroid use, antiviral agents and herbal remedies specific for the liver were prohibited. Tuberculosis screening was conducted by inquiring about exposure and previous infection history, chest $\mathrm{x}$-ray and tuberculin skin testing. Active tuberculosis or a tuberculin skin reaction $>5 \mathrm{~mm}$ precluded eligibility.

Participants were randomly assigned to receive either a single pretreatment induction infusion of infliximab $(5 \mathrm{mg} / \mathrm{kg})$ seven days before antiviral therapy or no pretreatment. All patients received pegylated IFN- $\alpha 2 \mathrm{~b}(1.5 \mu \mathrm{g} / \mathrm{kg} / \mathrm{wk})$ plus weight-based ribavirin $(800 \mathrm{mg} / \mathrm{day}$ to $1400 \mathrm{mg} /$ day) for up to 48 weeks.

HCV RNA levels were assessed before infliximab dosing, on day 0 of HCV antiviral therapy, and at weeks 2, 4, 6, 8, 12, 24, 48 and 72. $\mathrm{HCV}-\mathrm{RNA}$ results were given in $\mathrm{IU} / \mathrm{mL}(1 \mathrm{IU} / \mathrm{mL} \times 2.7 \mathrm{copies} / \mathrm{IU}=$ copies $/ \mathrm{mL})$. HCV was quantified using polymerase chain reaction for HCV RNA. Initially, the Amplicor HCV Monitor test (Roche Diagnostics, Canada) was used. The test is specifically designed for assessing viral load with the low linear sensitivity $6 \times 10^{2}$ and lower limit of detection (ie, $50 \mathrm{IU} / \mathrm{mL}$ ). The procedure is based on five major steps required by the specimen preparation, reverse transcription of target RNA to generate complementary DNA, polymerase chain reaction amplification of target complementary DNA using HCVspecific complementary primers, hybridization of the amplified DNA to oligonucleotide probes specific to the target and detection of the probe bind amplifier. The lower limit of detection is $15 \mathrm{IU} / \mathrm{mL}$. For the final 30 patients enrolled in the study, the newly automated, sensitive method CobasAmpliprep-Amplicor/Taqman HCV test (Roche
Diagnostics, Canada) was used. The equivalence of the methods were validated. To ascertain the validity of the conclusions, the HCV RNA of the SVRs that have been judged by Amplicor HCV Monitor has been retested using the Taqman HCV test.

TNF- $\alpha$ levels $(\mathrm{pg} / \mathrm{mL})$ were quantitatively determined in serum using ELISA at the same time points. Cytoscreen immunoassay kits (Biosource International, InVitrogen, USA) were used, with a sensitivity and specificity of $96 \%$ and $92 \%$, respectively. Standards and reference reagents, available from the National Institute for Biological Standards and Controls (Herts, United Kingdom), were used. These methods are standardized in one of the author's (MN) laboratory according to the procedures described (5-7).

Clinical and laboratory safety measures where determined at each visit. The Short-Form 36 quality of life questionnaire was completed by the patient at the screening visit, at treatment weeks 12 and 48, and at week 72 before any study visit procedures.

As a primary outcome, the SVR 24 weeks before completion of therapy was compared between randomized treatment arms. The rapid virological response (RVR) at week 4 and complete early virological responses (EVR) at week 12 were assessed as secondary outcomes. Safety was also evaluated as a secondary outcome. The originally planned target of 96 participants provided $80 \%$ power to identify a clinically relevant increase in SVR from $48 \%$ to $75 \%$ assuming a $15 \%$ drop-out rate. However, enrollment was interrupted at 89 participants due to slow accrual. Efficacy analysis was conducted on a modified intent-to-treat population, defined as all participants receiving at least one dose of study medication. Descriptive statistics were performed for all study variables. Between-group differences were tested for statistical significance using Fisher's exact test. Viral outcome measures were assessed using univariable and multivariable logistic regression.

All sites obtained local research ethics approval before initiation of the present study. All participants provided informed consent.

\section{RESULTS}

Eighty-five of 89 randomized patients (70\% male) received pegylated IFN- $\alpha 2 \mathrm{~b}$ and ribavirin and were included in the modified intent-totreat analysis (Figure 1). Forty-three received infliximab and 46 did not. Mean age ( 48.1 years), race $(81 \%$ white) and METAVIR liver fibrosis stage $(\mathrm{FO}-2=79 \%, \mathrm{~F} 3-4=21 \%)$ were similar between randomized groups (Table 1). Interferon dose per $\mathrm{kg}$ and ribavirin dose per $\mathrm{kg}$ were similar according to group (data not shown).

Forty-eight participants (56.5\%) completed the study (21 infliximab recipients and 27 controls). Over the course of the study, 37 (43.5\%) discontinued prematurely (20 infliximab recipients and 17 controls). Treatment arms did not differ statistically in terms of mean treatment duration (infliximab recipients $=3.81$ months versus controls $=3.49$ months; $\mathrm{P}=0.29$ ). The majority of discontinuations were due to virological failure at week $12(n=20[23.5 \%])$ and week $24(n=7[8.2 \%])$ and did not differ statistically according to group.

No change in HCV RNA was observed in the week following infliximab dosing (data not shown). Following the initiation of HCV antiviral therapy, the slope of HCV RNA decay was similar between groups (Figure 2). A positive correlation between TNF- $\alpha$ and HCV RNA decline was identified that was similar between randomized groups (data not shown). Numerically lower proportions of patients achieved week 4 RVR (19.5\% versus 36.4\%), week 12 complete EVR $(43.9 \%$ versus $59.1 \%)$ and SVR 24 weeks after completion of therapy (34.1\% versus $52.3 \%)$ in infliximab recipients compared with the control arm. However, between-group differences did not reach statistical significance in any of these outcome measures based either on an observed case analysis or a dropout-equals-failure analysis. Although potentially limited by sample size, mean HCV RNA levels did not differ statistically at any time point over the course of the study. The mean time to undetectable HCV RNA was 109 days (95\% CI 88 to 130 days) in infliximab recipients and 83 days (95\% CI 64 to 101 days) in the control group $(\mathrm{P}=0.22)$ (Figure 2). 


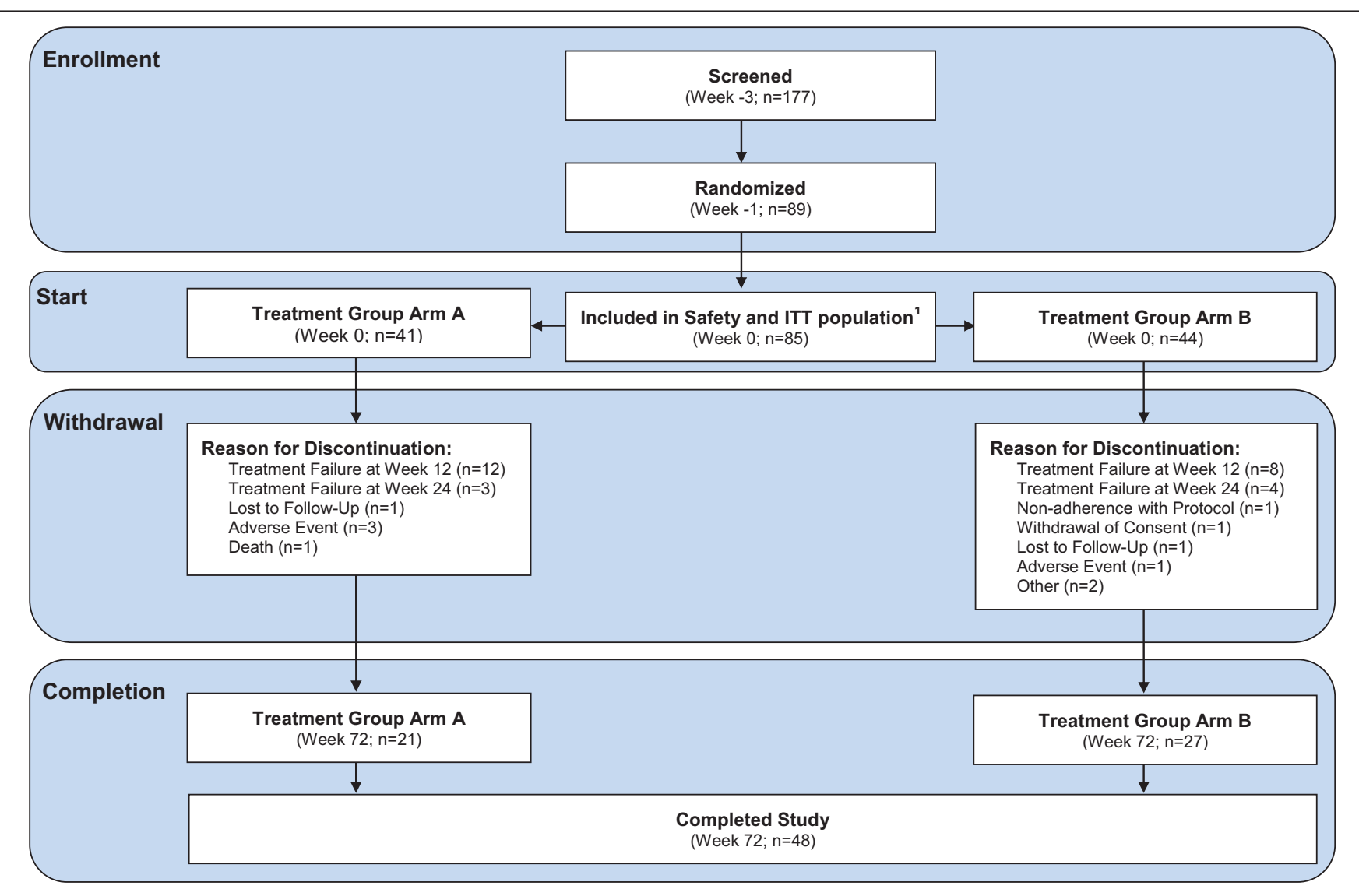

Figure 1) Participant flow diagram. Intent-to-treat (ITT) population defined as all randomized subjects who received at least one dose of study medication ( $n=85$ [89\%]; 70\% male). Four subjects did not receive any study medication. One patient reported two reasons for discontinuation including adverse event and treatment failure at week 24 in arm B. One patient completed the initial 17 visits but did not return at visit 18 (week 72); this patient was not considered as discontinued

TABLE 1

Patient demographics according to treatment group - ITT

\begin{tabular}{lcccc}
\hline & Arm A ( $\mathbf{n = 4 1 )}$ & Arm B ( $\mathbf{n}=\mathbf{4 4})$ & Total $(\mathbf{n = 8 5})$ & $\mathbf{P}$ \\
\hline Age, years & & & & \\
$\quad \begin{array}{l}\text { Mean (median) } \\
\text { Sex }\end{array}$ & $47.9(49.4)$ & $48.3(50.3)$ & $48.1(49.8)$ & $0.433^{*}$ \\
$\quad$ Male & $30(73.2)$ & $31(70.5)$ & $61(71.8)$ & $0.781^{\dagger}$ \\
$\quad$ Female & $11(26.8)$ & $13(29.5)$ & $24(28.2)$ & \\
Race & & & & \\
Caucasian & $32(78.0)$ & $37(84.1)$ & $69(81.2)$ & $0.239^{\dagger}$ \\
Asian & $5(12.2)$ & $3(6.8)$ & $8(9.4)$ & \\
Hispanic & $1(2.4)$ & $0(0.0)$ & $1(1.2)$ & \\
Black & $0(0.0)$ & $3(6.8)$ & $3(3.5)$ & \\
Native Indian & $1(2.4)$ & $1(2.3)$ & $2(2.4)$ & \\
Other ${ }^{\ddagger}$ & $2(4.9)$ & $0(0.0)$ & $2(2.4)$ &
\end{tabular}

Fibrosis score - historical liver biopsy (METAVIR System)

\begin{tabular}{lcccc} 
F0 & $0(0.0)$ & $1(2.3)$ & $1(1.2)$ & $0.688 \S$ \\
F1 & $15(36.6)$ & $18(40.9)$ & $33(38.8)$ & \\
F2 & $17(41.5)$ & $16(36.4)$ & $33(38.8)$ & \\
F3 & $9(22.0)$ & $8(18.2)$ & $17(20.0)$ \\
F4 & $0(0.0)$ & $1(2.3)$ & $1(1.2)$ \\
\hline
\end{tabular}

Data presented as $n(\%)$ unless otherwise indicated. Percentages are based on the total number of patients with available data in each group (Arm A Infliximab recipients; Arm B Control arm) at each visit. *Assessed with the independent samples $\mathrm{t}$ test for continuous variables; ${ }^{\dagger}$ Assessed using the Fisher's exact test for categorical variables; $¥$ Other includes a multiracial $(n=1)$ and Métis ( $n=1)$ participant; ${ }^{\S}$ Assessed using the Pearson $\chi^{2}$ test. ITT Intent to treat

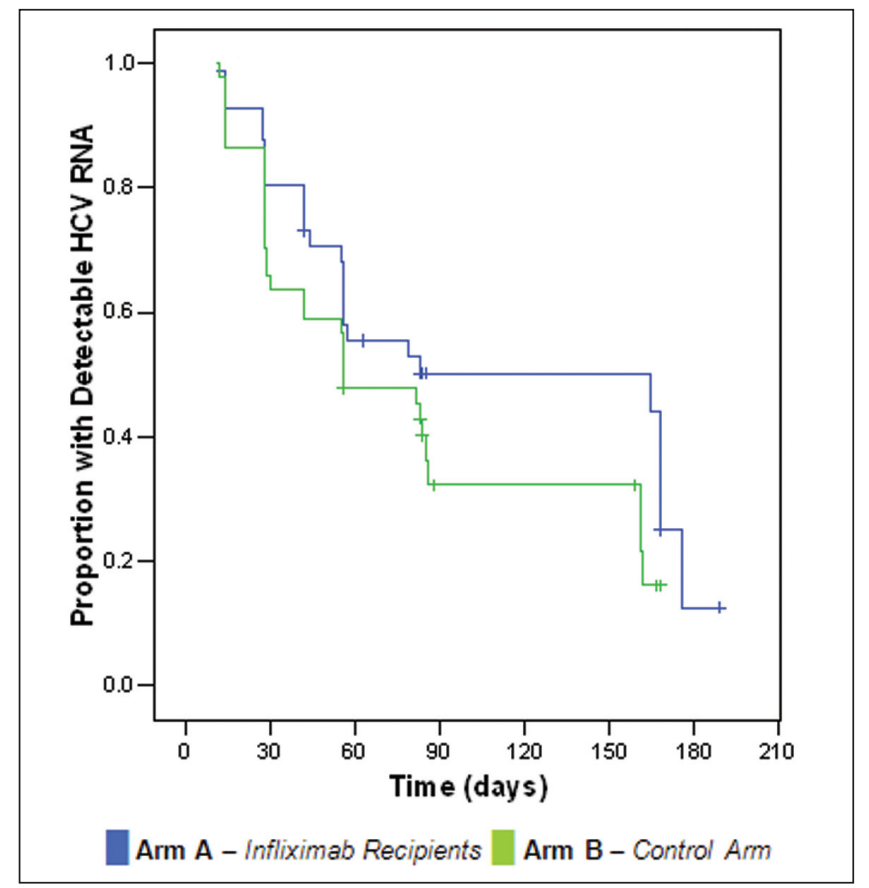

Figure 2) Time to undetectable hepatitis $\mathrm{C}$ virus (HCV) RNA levels - intention to treat. Following the initiation of $\mathrm{HCV}$ antiviral therapy, the slope of HCV RNA decay was similar between groups. The mean time to undetectable HCV RNA was 109 days (95\% CI 88 to 130 days) in infliximab recipients and 83 days (95\% CI 64 to 101 days) in the control group $(P=0.22)$ 
TABLE 2

Rapid virological response according to fibrosis score - intent to treat

\begin{tabular}{|c|c|c|c|c|c|c|c|}
\hline \multirow[b]{2}{*}{ Fibrosis score } & \multicolumn{2}{|c|}{$\operatorname{Arm} A(n=41)$} & \multicolumn{2}{|c|}{ Arm B $(n=44)$} & \multicolumn{2}{|c|}{ Total $(n=85)$} & \multirow[b]{2}{*}{$\mathbf{P}^{*}$} \\
\hline & Yes & No & Yes & No & Yes & No & \\
\hline $\mathrm{F} 1$ & $5(33.3)$ & $10(66.7)$ & $6(33.3)$ & $12(66.7)$ & $11(33.3)$ & $22(66.7)$ & $>0.999$ \\
\hline F3 & $1(11.1)$ & $8(88.9)$ & $2(25.0)$ & $6(75.0)$ & $3(17.6)$ & $14(82.4)$ & 0.576 \\
\hline F4 & $0(0.0)$ & $0(0.0)$ & $0(0.0)$ & $1(100.0)$ & $0(0.0)$ & $1(100.0)$ & $\mathrm{NC}$ \\
\hline
\end{tabular}

Data presented $n(\%)$ unless otherwise indicated. Percentages are based on the total number of patients with available data in each group at each visit. ${ }^{*}$ Assessed with the Fisher's Exact test; ${ }^{\dagger}$ Statistically significant result. Arm A Infliximab recipients; Arm B Control arm; NC Not calculable

TABLE 3

Complete early virological response according to fibrosis score - intent to treat

\begin{tabular}{|c|c|c|c|c|c|c|c|}
\hline \multirow[b]{2}{*}{ Fibrosis score } & \multicolumn{2}{|c|}{$\operatorname{Arm} A(n=41)$} & \multicolumn{2}{|c|}{ Arm B $(n=44)$} & \multicolumn{2}{|c|}{ Total $(n=85)$} & \multirow[b]{2}{*}{$\mathbf{P}^{*}$} \\
\hline & Yes & No & Yes & No & Yes & No & \\
\hline F0 & $0(0.0)$ & $0(0.0)$ & $0(0.0)$ & $1(100.0)$ & $0(0.0)$ & $1(100.0)$ & $\mathrm{NC}$ \\
\hline $\mathrm{F} 1$ & $6(42.9)$ & $8(57.1)$ & $13(76.5)$ & $4(23.5)$ & 19 (61.3) & $12(38.7)$ & 0.075 \\
\hline F2 & $10(62.5)$ & $6(37.5)$ & $10(71.4)$ & $4(28.6)$ & $20(66.7)$ & $10(33.3)$ & 0.709 \\
\hline F3 & $2(25.0)$ & $6(75.0)$ & $3(37.5)$ & $5(62.5)$ & $5(31.3)$ & $11(68.8)$ & $>0.999$ \\
\hline F4 & $0(0.0)$ & $0(0.0)$ & $0(0.0)$ & $1(100.0)$ & $0(0.0)$ & $1(100.0)$ & $\mathrm{NC}$ \\
\hline
\end{tabular}

Data presented as $n$ (\%) unless otherwise indicated. Percentages are based on the total number of patients with available data in each group at each visit. *Assessed using Fisher's exact test. Arm A Infliximab recipients; Arm B Control arm; NC Not calculable

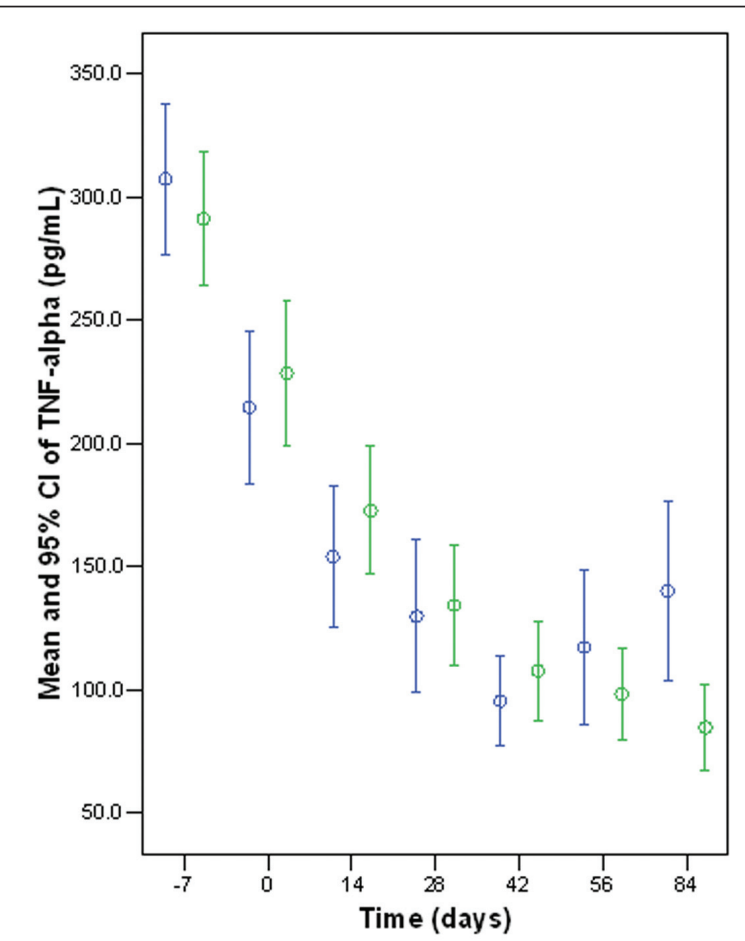

Arm A - Infliximab Recipients Arm B - Control Arm

Figure 3) Tumour necrosis factor-alpha (TNF- $\alpha$ ) levels at each visit according to treatment group. The baseline levels of TNF- $\alpha$ were similar between study arms. A rapid decline in serum TNF- $\alpha$ level was noted one week following dosing of infliximab and preceeding the initial dosing of pegylated interferon $\alpha-2 b$ and ribavirin. This rapid decline continued following the dosing of pegylated interferon $\alpha-2 b$ and ribavirin, and positively correlated with hepatitis $C$ virus RNA decline over the initial four weeks of dosing. However, the slope of decline was similar in both groups, irrespective of infliximab dosing

RVR and EVR were assessed as a function of fibrosis (Tables 2 and 3). As would be expected, RVR and EVR diminished with advancing fibrosis. No consistent difference was observed between randomized groups.

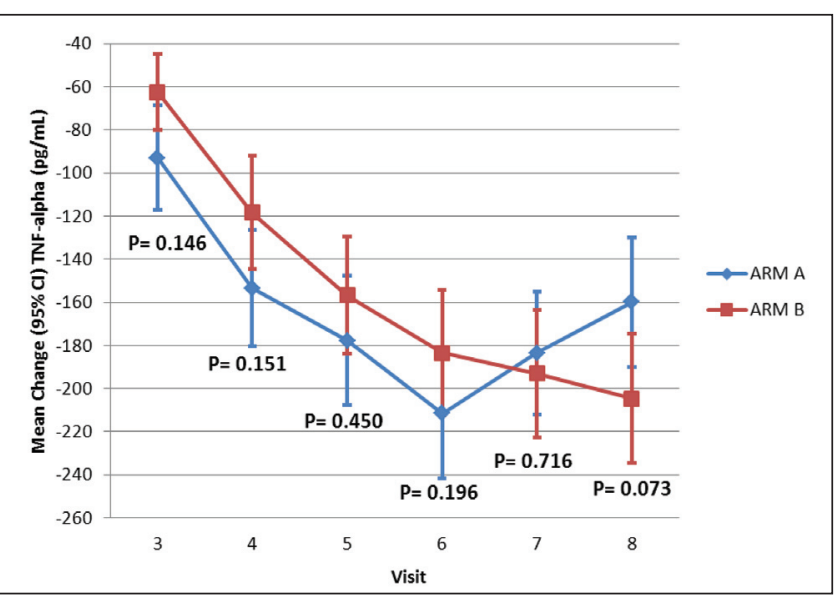

Figure 4) Changes in tumour necrosis factor-alpha (TNF- $\alpha$ ) levels between day 0 (visit 3) and week 12 (visit 8). Between-group P value, assessed using independent samples $t$ test, revealed no statistical differences in the decline of unadjusted mean change of serum TNF- $\alpha$ in the two arms between day 0 (visit 3) and week 12 (visit 8) of pegylated interferon and ribavirin therapy. A numerical difference in the value of serum TNF-a level was observed until week 6 (visit 6), suggesting a larger reduction in inflammation in treatment arm A (infliximab recipients) compared with arm B (control arm). The effect dissipated over time

Figure 3 illustrates the kinetics of serum TNF- $\alpha$ during the entire study. The baseline levels of TNF- $\alpha$ were similar between study arms. Figure 4 illustrates the decline of serum TNF- $\alpha$ levels in the two arms between day 0 (visit 3 ) and week 12 (visit 8 ). There were no statistical differences between the two arms. However, until week 6 (visit 6) there was a numerical difference in the value of serum TNF- $\alpha$, suggesting a larger reduction in inflammation in treatment arm A compared with arm B. The effect dissipated over time.

In general, laboratory parameters, vital signs and physical examination were stable, and similar between study arms and most visits. Specifically, the slope of aspartate and alanine aminotransferase level decline was similar according to group (data not shown). No differences between infliximab recipients and control participants in quality of life scores were identified over the course of treatment (data not shown). Infliximab was well tolerated without attributable severe adverse events. Over the course of the 72-week study, a total of 1147 treatment-emergent 
adverse events were reported in $100 \%$ of participants. Of these, 21 serious adverse events (SAE) in $12(14.1 \%)$ participants were identified. Possible or probable relationship to the study drug was assigned in eight of 10 SAEs in infliximab-recipients and seven of 11 in the control arm. One participant discontinued therapy due to a SAE (lobar pneumonia) in the infliximab-recipient group. This SAE was determined to be likely related to study drug. One death due to arteriosclerosis coronary artery disease occurred in the infliximab arm, which was judged to be not likely related to the study drug.

\section{DISCUSSION}

The use of a single dose of TNF- $\alpha$ inhibitor was demonstrated to be safe and well tolerated in HCV-infected study participants, corroborating the current body of evidence (13). However, there was no evidence of any beneficial effect on HCV RNA decline, SVR or alanine aminotransferase response. This is consistent with other studies that have assessed the influence of TNF- $\alpha$ inhibition on liver enzymes and viremia (14). In contrast to our results, a pilot study evaluating the influence of TNF- $\alpha$ inhibition on HCV treatment outcome demonstrated both improved tolerability of interferon-based treatment and improved on-treatment virological response (15). Of note, SVR rates did not differ significantly between etanercept $(42 \%)$ and placebo $(32 \%)$ recipients. Potential explanations for the differences between our study results and those of Zein (15) include the use of multiple doses of TNF- $\alpha$ inhibitor while on antiviral therapy, the use of a different TNF- $\alpha$ inhibitor (ie, etanercept) and a small sample size, increasing the risk of a type II statistical error. In our study, there was no evidence of improved pegylated IFN and ribavirin tolerance in the weeks immediately following dosing and no evidence of more rapid virological decline within the first four weeks of HCV antiviral therapy; a period in which we would have expected a maximal effect of infliximab, if present. Furthermore, no difference in on-treatment liver enzyme level decline was identified.

A rapid decline in serum TNF- $\alpha$ level was noted one week following dosing of infliximab and proceeding the initial dosing of pegylated IFN $\alpha-2 b$ and ribavirin (Figure 3 ). This rapid decline continued following the dosing of pegylated IFN $\alpha-2 b$ and ribavirin and positively correlated with HCV RNA decline over the initial four weeks of dosing. However, the slope of decline was similar in both groups, irrespective of infliximab dosing. Serum TNF- $\alpha$ levels $>300 \mathrm{pg} / \mathrm{mL}$ at screening were required for inclusion. We noted that at the time of infliximab dosing, levels were lower than this cut-point, which is likely indicative of a regression to the mean phenomenon. This may have served to diminish the impact of infliximab. We do not believe that this change in TNF- $\alpha$ level from screening to infliximab dosing was due to altered alcohol consumption because excess alcohol use was an exclusionary for participation in the present study. A subanalysis of those with serum TNF- $\alpha$ levels $>300 \mathrm{pg} / \mathrm{mL}$, both at screening and at the time of infliximab dosing, did not reveal any evidence that this was the case (data not shown). The observation that the slope of serum TNF- $\alpha$ decline was similar with pegylated IFN $\alpha-2 b$ and ribavirin dosing, irrespective of infliximab administration, indicated that these HCV antiviral medications and/or their influence on HCV infection have a far more potent influence on serum TNF- $\alpha$ levels than infliximab in the context of chronic HCV infection.

The strengths of the present study include the randomized allocation of treatment and frequent clinical and laboratory monitoring of participants. However, several limitations are acknowledged. First, the study lasted longer than expected and was interrupted before the calculated sample size was achieved. Also, the assay used to quantify HCV RNA was changed midway through the conduct of the study. Although not ideal, we do not believe that this had a major influence on our findings because only 15 of 89 (17\%) of participants underwent HCV RNA evaluations using both assays. Furthermore, the initial 12 weeks of HCV RNA testing was conducted using either one or the other assay but not both. As well, it is unlikely that the primary outcome (SVR) would be misclassified given the minimal difference in lower limit of detection between assays (ie, $50 \mathrm{IU} / \mathrm{mL}$ versus $15 \mathrm{IU} / \mathrm{mL}$ ) because HCV RNA levels would have fully rebounded to baseline levels by week 24 post-therapy in unsuccessful HCV antiviral recipients. Interleukin (IL) $28 \mathrm{~B}$ status was unavailable for our analysis because the present study was conducted before the identification of this as a key predictor of HCV antiviral outcome (16). Although it is likely that IL28B distribution was balanced between treatment arms in the present randomized study, it would have been valuable to evaluate the influence of infliximab as a function of IL28B genotype.

\section{CONCLUSION}

Infliximab can be safely administered to patients infected with $\mathrm{HCV}$. This is clinically relevant because HCV infection is occasionally identified in those with concurrent disorders requiring TNF- $\alpha$ inhibitor therapy $(13,14,17)$. Our study demonstrates that manipulation of endogenous TNF- $\alpha$ levels with a single dose of infliximab treatment proceeding combination pegylated IFN $\alpha-2 b$ and ribavirin therapy does not result in greater viral decline during the first 12 weeks of therapy or improved SVR rates, and should not be considered as an adjunctive treatment for HCV.

ACKNOWLEDGEMENTS: The authors thank the participants, research associates and monitors who contributed to this study and JSS for statistical analysis. Special thanks to J-F Pouliot, P Egli, E Levesque and Schering-Plough-Merck PEGADE team that enabled the study. Schering-Plough-Merck provided the investigational drugs and funded this work. Dr Neuman greatly appreciates the assistance of D Murphy and J Chamberland, Institute Nationale de Santé Publique du Québec, for contributing their assistance in validating the TaqMan ${ }^{\circledR}$ HCV Test methodology.

\section{REFERENCES}

1. Koziel MJ, Dudley D, Afdhal N, et al. Hepatitis C virus (HCV)specific cytotoxic $\mathrm{T}$ lymphocytes recognize epitopes in the core and envelope proteins of HCV. J Virol 1993;67:7522-32.

2. Jacobson Brown PM, Neuman MG. Immunopathogenesis of hepatitis $\mathrm{C}$ viral infection: Th1/Th2 responses and the role of cytokines. Clin Biochem 2001;34:167-71.

3. Koziel MJ. Cytokines in viral hepatitis. Semin Liver Dis 1999;19:157-69.

4. Tilg H, Wilmer A, Vogel W, et al. Serum levels of cytokines in chronic liver diseases. Gastroenterology 1992;103:264-74.

5. Neuman MG, Benhamou JP, Martinot M, et al. Predictors of sustained response to alpha interferon therapy in chronic hepatitis $\mathrm{C}$ Clin Biochem 1999;32:537-45.

6. Neuman MG, Benhamou JP, Bourliere M, et al. Serum tumour necrosis factor-alpha and transforming growth factor-beta levels in chronic hepatitis $\mathrm{C}$ patients are immunomodulated by therapy. Cytokine 2002;17:108-17.

7. Neuman MG, Benhamou JP, Malkiewicz IM, et al. Cytokines as predictors for sustained response and as markers for immunomodulation in patients with chronic hepatitis $\mathrm{C}$. Clin Biochem 2001;34:173-82.

8. Fukuda R, Ishimura N, Ishihara S, et al. Intrahepatic expression of pro-inflammatory cytokine mRNAs and interferon efficacy in chronic hepatitis C. Liver 1996;16:390-9.

9. Larrea E, Garcia N, Qian C, Civeira MP, Prieto J. Tumor necrosis factor alpha gene expression and the response to interferon in chronic hepatitis C. Hepatology 1996;23:210-7.

10. Neuman MG, Benhamou JP, Malkiewicz IM, et al. Kinetics of serum cytokines reflect changes in the severity of chronic hepatitis $\mathrm{C}$ presenting minimal fibrosis. J Viral Hepat 2002;9:134-40.

11. Nahar IK, Shojania K, Marra CA, Alamgir AH, Anis AH. Infliximab treatment of rheumatoid arthritis and Crohn's disease. Ann Pharmacother 2003;37:1256-65.

12. Gonzalez-Amaro R, Garcia-Monzon C, Garcia-Buey L, et al. Induction of tumor necrosis factor alpha production by human hepatocytes in chronic viral hepatitis. J Exp Med 1994;179:841-8. 
13. Brunasso AM, Puntoni M, Gulia A, Massone C. Safety of anti-tumour necrosis factor agents in patients with chronic hepatitis $\mathrm{C}$ infection: A systematic review. Rheumatology (Oxford) 2011;50:1700-11.

14. Peterson JR, Hsu FC, Simkin PA, Wener MH. Effect of tumour necrosis factor alpha antagonists on serum transaminases and viraemia in patients with rheumatoid arthritis and chronic hepatitis C infection. Ann Rheum Dis 2003;62:1078-82.

15. Zein NN. Etanercept as an adjuvant to interferon and ribavirin in treatment-naive patients with chronic hepatitis $\mathrm{C}$ virus infection: A phase 2 randomized, double-blind, placebo-controlled study. J Hepatol 2005;42:315-22.
16. Ge D, Fellay J, Thompson AJ, et al. Genetic variation in IL28B predicts hepatitis $\mathrm{C}$ treatment-induced viral clearance. Nature 2009;461:399-401.

17. Li S, Kaur PP, Chan V, Berney S. Use of tumor necrosis factor-alpha (TNF-alpha) antagonists infliximab, etanercept, and adalimumab in patients with concurrent rheumatoid arthritis and hepatitis B or hepatitis C: A retrospective record review of 11 patients. Clin Rheumatol 2009;28:787-91. 


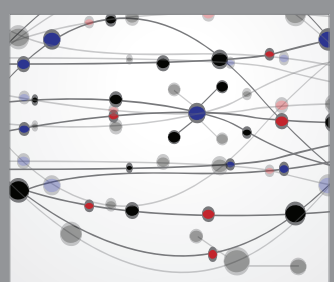

The Scientific World Journal
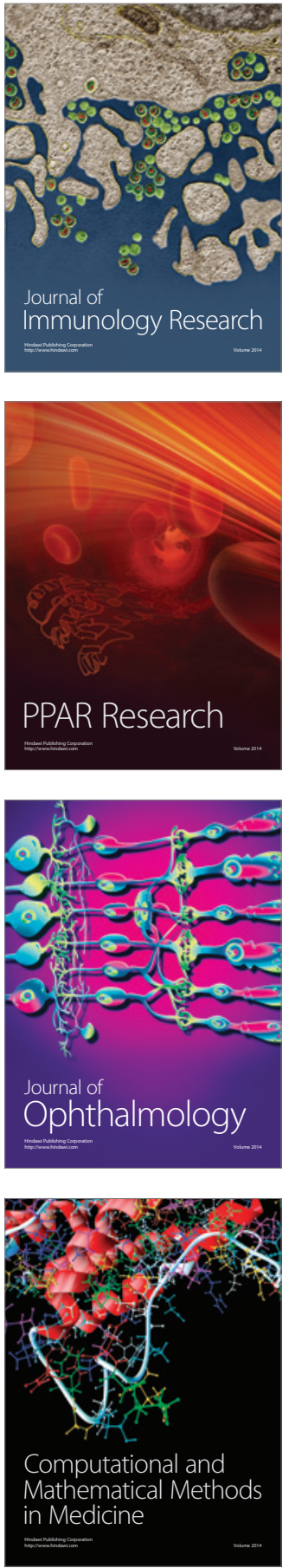

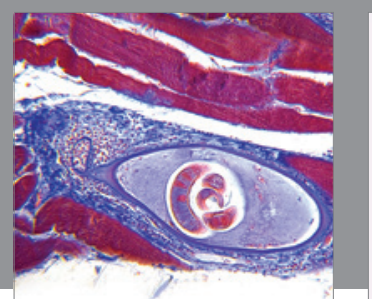

Gastroenterology Research and Practice

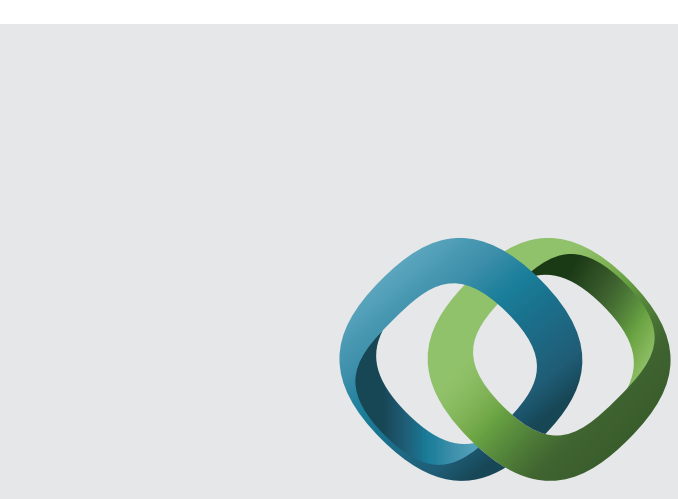

\section{Hindawi}

Submit your manuscripts at

http://www.hindawi.com
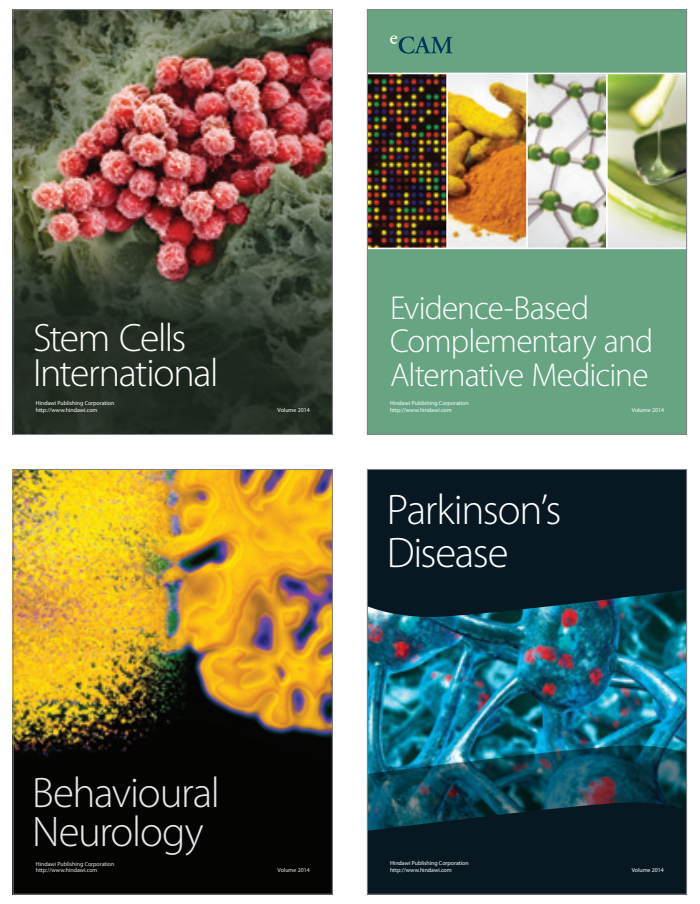
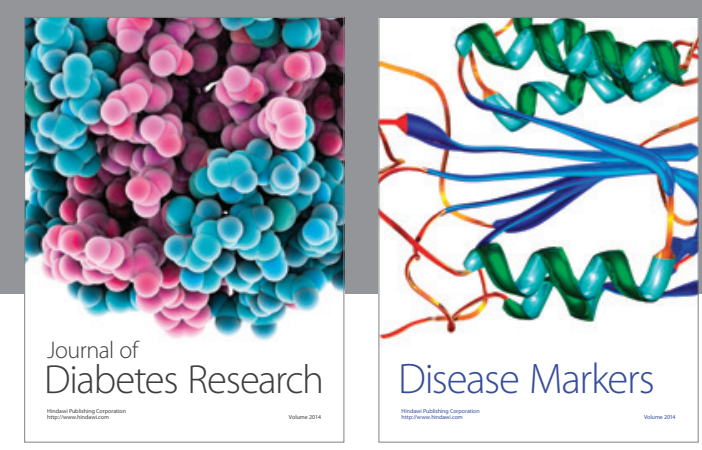

Disease Markers
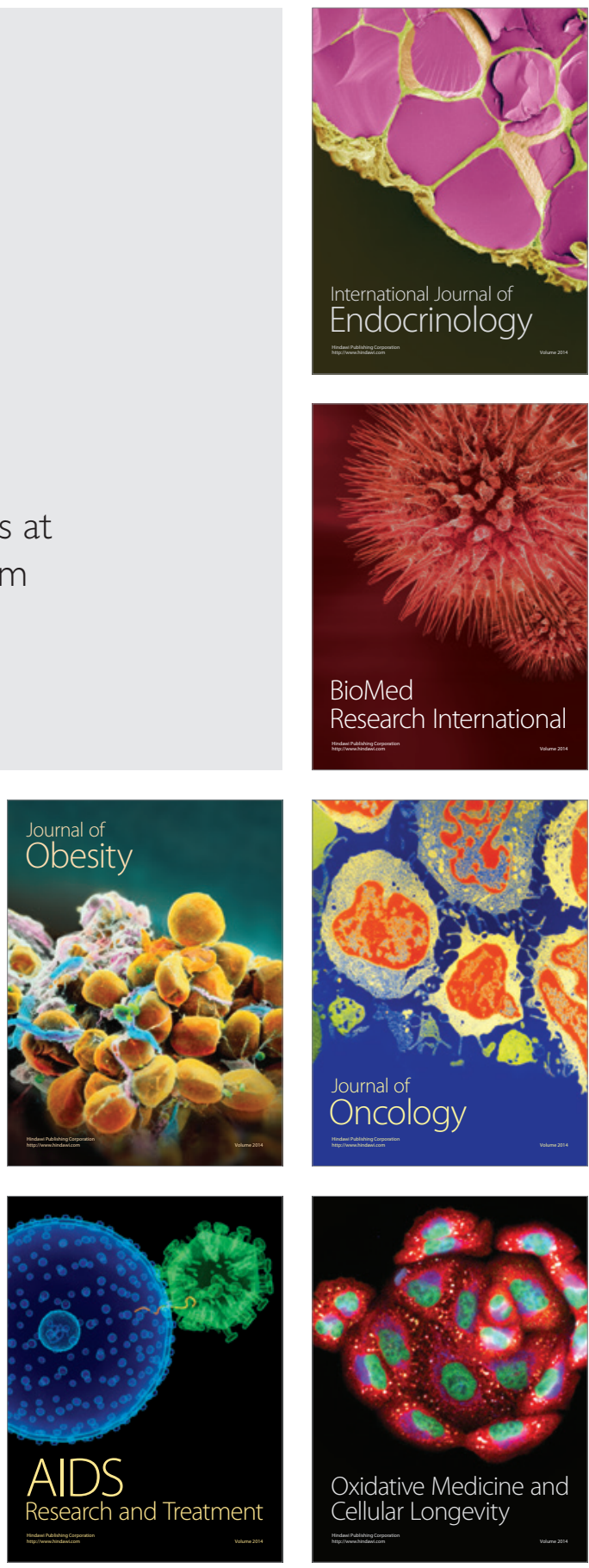